\title{
ALK inhibitors in NSCLC- crizotinib and beyond
}

Abbreviations: EGFR, epidermal growth factor receptor; ALK-EML4, anaplastic lymphoma kinase echinoderm microtubuleassociated protein-like 4; NSCLC, non-small cell lung cancer; PFS, progression free survival; RR, response rate; CNS, central nervous system; HR, hazard ratio; FDA, food and drug administration; mg, milligram

\section{Introduction}

Lung cancer is the most common cancer diagnosed in developed countries, and it is the leading cause of cancer related death worldwide. ${ }^{1}$. Over $70 \%$ of lung cancer patients are diagnosed with advanced disease at presentation, and receive palliative treatment only. Until a decade ago, the treatment included chemotherapy alone, with a limited survival benefit. ${ }^{2}$

The identification of molecular subtypes of NSCLC revolutionized the treatment for patients diagnosed with NSCLC harboring molecular alterations. The most common are the EGFR mutation; which is found at $10-15 \%$ of patient, and the $A L K-E M L 4$ rearrangement. ${ }^{3}$, which is found at $4-7 \%$ of patients. Several ALK tyrosine kinase inhibitors were developed in the last decade, and we hereby review the current and future ALK inhibitors and the up to date treatment of ALKrearranged NSCLC.

\section{Currently approved ALK inhibitors}

The detection of ALK rearrangement has changed the treatment and prognosis in this subgroup of patients. Crizotinib, which was originally developed for treatment of anaplastic large-cell lymphoma. ${ }^{4}$ Table 1 was the first ALK inhibitor to be approved by the FDA in November 2014 for treatment of ALK rearranged NSCLC in the second line setting. The approval was based on the results of the PROFILE 1007, with PFS of 7.7 months, compare to 3months in the chemotherapy arm, and the RR was $65 \% .{ }^{5}$ Crizotinib waslater on approved for the 1 st line treatment based on the results of the PROFILE 1014 phase III trial, showing PFS of 10.9 months vs. 7 months, and RR of $74 \%$ vs. $45 \%$ in the Crizotinib and chemotherapy arm, respectively. ${ }^{6}$ The toxicity profile of crizotinib is different from chemotherapy, and includes vision disorders, diarrhea, nausea, vomiting, constipation, elevated liver aminotransferase levels and edema (Table 1). Currently, crizotinib is the standard 1st line treatment for NSCLC harboring ALK rearrangement, although most of the patients will develop resistance to treatment after a median of 10 months. Resistance to treatment is uasually related to the emergence of new resistant clones. ${ }^{7}$ About a quarter of patients with ALK-rearranged NSCLC will have CNS involvement at time of diagnosis, and that site is the most frequent site of disease progression. ${ }^{8}$ The inevitable resistance to treatment raised the need for new ALK inhibitors, with high penetrance of the bloodbrain barrier and activity against the resistant clones in the second line setting and beyond.

Ceritinib was the next agent to demonstrate high anti-tumor activity for patients who progressed on crizotinib, as well as higher rate of CNS penetration. The drug was approved by the FDA in the second line setting in April 2014 in accelerated process after a phase I trialthe ASCEND 1 trial, which showed high RR among both crizotinib naïve and pretreated patients, of $58 \%$ and $56 \%$, respectively. ${ }^{9}$ Ceritinib has also showed prolonged duration of response, more than 8 months in the pretreated patientsIn the first line setting, ceritinib demonstrated
Volume 8 Issue 3 - 2017

\author{
Albaba Hamzeh, Moskovitz Mor \\ Department of Medical Oncology and Hematology, Princess \\ Margaret Cancer Centre, University of Toronto, Canada \\ Correspondence: Albaba Hamzeh, Department of Medical \\ Oncology and Hematology, Princess Margaret Cancer Centre, \\ University of Toronto, Toronto, ON, Canada, \\ Email hamza_baba829082@yahoo.com \\ Received: May 19, 2017 | Published: August 02, 2017
}

superiority over chemotherapy, with PFS of 16.6 months vs. 8.1 months on the chemotherapy arm $(\mathrm{HR}=0.55)$. The toxicity profile of ceritinib included mostly GI toxicity, with diarrhea, nausea and vomiting (Table 1). ${ }^{10}$

The third ALK inhibitor approved in December 2015 was Alectinib, after 2 phase II clinical trials. ${ }^{11}$ demonstrating PFS of 8.1 to 8.9 months and RR around $50 \%$ in pretreated patients. The toxicity profile of alectinib is considered favorable, and includes headache, neutropenia, fatigue, myalgia, peripheral edema, liver enzyme abnormality and hypophosphatemia. Alectinib also has improved CNS activity (Table 1).

\section{Future ALK inhibitors}

Additional ALK inhibitor approved in April 2017 was Brigatinib. ${ }^{12}$ (Table 1), which demonstrated PFS of 8.8 months with the daily dose $90 \mathrm{mg}$, and 11.1 months with the $180 \mathrm{mg}$ dose, although the starting dose will be $90 \mathrm{mg}$. The overall RR was $46 \%$ and $54 \%$ in each arm, respectively. Several other ALK inhibitors are currently under investigation (Table 1), such as Lorlatinib, ${ }^{13}$ which similarly to Crizotinib, also acts as a ROS- 1 inhibitor, and results from phase II and phase III clinical trials are pending.

\section{Sequence of treatment}

The best sequence of treatment for ALK-rearranged NSCLC patients is not clear yet, and several trials are comparing the different ALK inhibitors in first line setting to establish the preferred order of agents. The multinational phase III ALEX trial is comparing alectinib to crizotinib in the first line setting, and data from the Japanese subgroup has showen significant improvement in the PFS in the alectinib group, with $\mathrm{HR}=0.34$ and a PFS of 10.2 months in the crizotinib arm vs. PFS not reached in the alectinib arm. ${ }^{14}$ The final data from this trial demonstrated favorable PFS of alectinib (not reached vs. 11.1months with crizotinib), and hazard ratio of $0.47 . .^{15}$ 
Table I Characteristics of different ALK inhibitors in NSCLC

\begin{tabular}{|c|c|c|c|c|c|}
\hline Agent & Standard dose & Additional targets & Mechanism of resistance & PFS in months & Side effects \\
\hline $\begin{array}{l}\text { Crizotinib } \\
\text { (Xalkori) I6-20 }\end{array}$ & $\begin{array}{l}250 \mathrm{mg} \text { twice } \\
\text { daily }\end{array}$ & $\begin{array}{l}\text { C-MET } \\
\text { ROSI }\end{array}$ & $\begin{array}{l}\text { Mutations in LI I96M (Gatekeeper), } \\
\text { LI I52R, CI I56Y, I I I I Iins, G I 202R, } \\
\text { SI 206Y, and GI 269A, FI I 74L ALK/ } \\
\text { EGFR/KIT amplification, KRAS } \\
\text { mutation }\end{array}$ & $\begin{array}{l}\text { 2nd line } 7.7 \mathrm{~m} \\
\text { Ist line } 10.9 \mathrm{~m}\end{array}$ & $\begin{array}{l}\text { Visual disturbance, nausea, } \\
\text { diarrhea, elevated liver enzymes, } \\
\text { lymphopenia, pneumonitis, } \\
\text { hypophosphatemia, pulmonary } \\
\text { embolism }\end{array}$ \\
\hline $\begin{array}{l}\text { Ceritinib } \\
\text { (Zykadia)26-28, } 74\end{array}$ & 750mg once daily & $\begin{array}{l}\text { IGF-IR } \\
\text { STK22D } \\
\text { PLT3 Alectinib } \\
\text { resistant mutation } \\
\text { III I IT/N/S }\end{array}$ & & $7 m$ & $\begin{array}{l}\text { diarrhea, vomiting, nausea, } \\
\text { dehydration, elevated liver } \\
\text { enzymes, hypophosphatemia }\end{array}$ \\
\hline $\begin{array}{l}\text { Alectinib (Alecensa) } \\
34-37\end{array}$ & $\begin{array}{l}\text { 600mg twice } \\
\text { daily }\end{array}$ & $\begin{array}{l}\text { RET } \\
\text { Crizotinib resistant } \\
\text { mutation LI I96M }\end{array}$ & III7IT/N/S mutations & $8.1-8.9 m$ & $\begin{array}{l}\text { Headache, neutropenia, fatigue, } \\
\text { myalgia, peripheral edema, } \\
\text { liver enzyme abnormality, } \\
\text { hypophosphatemia. }\end{array}$ \\
\hline Brigatinib (Alunbrig) & $\begin{array}{l}\text { Arm A:90 } \\
\text { Arm B: } 180 \mathrm{mg} \\
\text { once daily }\end{array}$ & $\begin{array}{l}\text { ROSI } \\
\text { EGFR } \\
\text { STK22D } \\
\text { PLT3 }\end{array}$ & & $\begin{array}{l}\text { A: } 8.8 \mathrm{~m} \\
\text { B: } 11.1 \mathrm{~m}\end{array}$ & $\begin{array}{l}\text { Nausea, diarrhea, fatigue, dyspnea, } \\
\text { increased lipase, hypoxia, elevated } \\
\text { liver enzymes and amylase. } \\
\text { pneumonia, pyrexia, pulmonary } \\
\text { embolism }\end{array}$ \\
\hline Lorlatinib & $100 \mathrm{mg}$ & $\begin{array}{l}\text { ROSI } \\
\text { Crizotinib resistant } \\
\text { mutation LI I96M } \\
\text { LTK (TYKI) }\end{array}$ & LII $98 F$ & - & $\begin{array}{l}\text { Hypercholesterole, peripheral } \\
\text { edema }\end{array}$ \\
\hline
\end{tabular}

NSCLC, non- small cell lung cancer; ALK, anaplastic lymphoma kinase; EGFR, epidermal growth factor receptor; KIT, tyrosine-protein kinase Kit; C-MET, tyrosine-protein kinase MET; ROSI, proto-oncogene tyrosine-protein kinase ROS; IGF-IR, insulin-like growth factor I receptor; STK22D, serine/threonine kinase; RET, RET proto-oncogene; PFS, progression free survival.

\section{Conclusion}

ALK TKIs have demonstrated favorable outcomes on ALK rearranged advanced NSCLC compare to standard chemotherapy, and became the standard of care for this subgroup of patients. Crizotinib is the current standard of care for 1st line treatment, and the new ALK TKIs, including ceritinib and alectinib, are used in advanced lines of treatment. Trials evaluating the sequence of ALK inhibitors are ongoing. There are several new ALK inhibitors currently assessed in clinical trials, and patients harboring the ALK rearrangement can benefit multiple lines of treatment with ALK TKI, which prolong their life.

\section{Acknowledgements}

None.

\section{Conflicts of interest}

The authors declare that there are no conflicts of interest.

\section{Funding}

None.

\section{References}

1. Siegel RL, Miller KD, Jemal A. Cancer statistics, 2015. CA Cancer J Clin. 2015;65:5-29.

2. Schiller $\mathrm{JH}$, Harrington $\mathrm{D}$, Belani $\mathrm{CP}$, et al. Comparison of four chemotherapy regimens for advanced non-small-cell lung cancer. $N$ Engl J Med. 2012;346(2):92-98.
3. Kris MG, Johnson BE, Berry LD, et al. Using multiplexed assays of oncogenic drivers in lung cancers to select targeted drugs. JAMA. 2014;311(19):1998-2006.

4. Li Y, Ye X, Liu J, et al. Evaluation of EML4-ALK fusion proteins in non-small cell lung cancer using small molecule inhibitors. Neoplasia. 2011;13:1-11

5. Shaw AT, Kim DW, Nakagawa K, et al. Crizotinib versus Chemotherapy in Advanced ALK -Positive Lung Cancer. $N$ Engl $\mathrm{J}$ Med. 2013;368(25):2385-2394.

6. Solomon BJ, Mok T, Kim DW, et al. al. First-Line Crizotinib versus Chemotherapy in ALK -Positive Lung Cancer. $N$ Engl $\mathrm{J}$ Med. 2014;371(23):2167-2177.

7. Katayama R, Khan TM, Benes C, et al. Therapeutic strategies to overcome crizotinib resistance in non-small cell lung cancers harboring the fusion oncogene EML4-ALK. Proc Natl Acad Sci U S A. 2011;108(18):7535-7540.

8. Costa DB, Shaw AT, Ou SH, et al. Clinical Experience With Crizotinib in Patients With Advanced ALK-Rearranged Non-Small-Cell Lung Cancer and Brain Metastases. J Clin Oncol. 2015;33(17):1881-1888.

9. Shaw AT, Kim DW, Mehra R, et al. Ceritinib in ALK-rearranged nonsmall-cell lung cancer. N Engl J Med. 2014;370(13):1189-1197.

10. Soria JC, Tan DS, Chiari R, et al. First-line ceritinib versus platinumbased chemotherapy in advanced ALK -rearranged non-small-cell lung cancer (ASCEND-4): a randomised, open-label, phase 3 study, Lancet. 2017;389(10072):917-929.

11. Shaw AT, Gandhi L, Gadgeel S, et al. investigators study, Alectinib in ALK-positive, crizotinib-resistant, non-small-cell lung cancer:a single-group, multicentre, phase 2 trial. Lancet Oncol. 2016;17(2):234 242 . 
12. Dong-Wan Kim, Marcello Tiseo, Myung-Ju Ahn, et al. Brigatinib in Patients With Crizotinib-Refractory Anaplastic Lymphoma KinasePositive Non-Small-Cell Lung Cancer:A Randomized, Multicenter Phase II Trial. J Clin Oncol. 2017;35(22):2490-2498.

13. B Solomon, T Bauer, E Felip, et al. Safety and efficacy of lorlatinib (PF06463922) from the dose-escalation component of a study in patients with advanced ALK+ or ROS1+ non-small cell, cell lung cancer (NSCLC. Journal of Clinical Oncology. 2016;34(15suppl):9009-9009.
14. H Nokihara, T Hida, M Kondo, et al. Alectinib (ALC) versus crizotinib (CRZ) in ALK-inhibitor naive ALK-positive non-small cell lung cancer (ALK+ NSCLC):Primary results from the J-ALEX. ASCO Annu Meet. 2016.

15. Shaw AT, Peters S, Mok $\mathrm{T}$, et al. Alectinib versus crizotinib in treatment-naive advanced ALK -positive non-small cell lung cancer (NSCLC):Primary results of the global phase III ALEX study. J Clin Oncol. 2017;35(18 suppl). 